\title{
Stigma pada Perempuan Singgle Parent dengan HIV Positif (Studi Kualitatif)
}

\author{
Stigma on Single Parent Women with Positive HIV \\ (Qualitative Study)
}

\author{
Dewi Damayanti ${ }^{1,}$, Rusmala Dewi $^{1}$ \\ ${ }^{1}$ Akademi Keperawatan, Panca Bhakti Bandar Lampung, Indonesia \\ ${ }^{\otimes}$ Corresponding author: ddamayanti1 @ yahoo.co.id
}

Kata kunci:
Stigma HIV,
Perempuan dengan
HIV,
Single parent.

Keyword:

Stigma HIV,

Women with HIV,

Single parent.

\begin{abstract}
Abstrak
Latar belakang: Hidup sebagai perempuan single parent dengan HIV positif memunculkan beragam stigma dimasyarakat. Purpose: Penelitian ini bertujuan untuk memperoleh gambaran stigma pada perempuan single parent dengan HIV positif. Metode: Penelitian ini merupakan penelitian kualitatif deskriftif dengan pendekatan konten analisis. Tehnik pengambilan data dilakukan dengan wawancara mendalam yang dilakukan pada 13 partisipan. Tehnik sampling yang digunakan purposive sampling. Data dianalisis dengan tehnik analisis konten konvensional. Hasil: Hasil penelitian membentuk 5 tema yaitu: mengalami stigma internal, mengalami stigma eksternal dan diskriminasi, memiliki anak sebagai motivator hidup tertinggi, mengalami kelelahan fisik berlebih, dan mengalami masalah dalam memulai interaksi dengan calon pasangan hidup baru. Simpulan: Perempuan single parent mengalami stigma ganda dengan status sebagai single parent dan HIV positif. Perempuan single parent dengan HIV membutuhkan dukungan yang lebih, dibandingkan perempuan HIV yang lain, oleh karena double stigma yang dirasakan oleh partisipan. Keluarga merupakan support sistem terbesar bagi perempuan single parent, dukungan dan bantuan keluarga dalam segala hal dirasakan sekali manfaatnya bagi partisipan.
\end{abstract}

\begin{abstract}
Background: Living as a single parent woman with HIV poses a variety of stigmas in the community. Purpose: This study aims to obtain a picture of stigma in single parent women with HIV positive. Methods: This research is a descriptive qualitative research with content analysis approach. Data collection techniques were carried out with in-depth interviews conducted on 13 participants. The sampling technique used was purposive sampling. Data were analyzed with conventional content analysis techniques. Results: The results of the study formed 5 themes, namely: experiencing internal stigma, experiencing external stigma and discrimination, having children as the highest life motivator, experiencing excessive physical fatigue, and having problems in starting interactions with potential life partners new. Conclusion: Single parent women experience double stigma with status as single parent and HIV positive. Single parent women with HIV need more support, compared to other HIV women, because of the double stigma felt by participants. The family is the biggest support system for single parent women, the support and assistance of the family in all things feels very beneficial for participants.
\end{abstract}

Copyright $@ 2017$ Jurnal Kesehatan Metro Sai Wawai. All rights reserved. 


\section{Pendahuluan}

Perkembangan penyakit HIV/AIDS sudah pada tingkat yang sangat memprihatinkan. Hal ini karena jumlah kasus AIDS yang dilaporkan setiap tahunnya meningkat secara signifikan. Laporan Epidemi AIDS Global (UNAIDS, 2012) menunjukkan bahwa terdapat 34 juta orang dengan HIV di seluruh dunia. Hingga saat ini, Indonesia masih merupakan negara di ASEAN yang paling tinggi pertumbuhan penularan HIV baru dimana terjadi peningkatan sebesar 162\% sejak tahun 2001 (UNAIDS, 2014).

Perempuan merupakan kelompok yang beresiko untuk terinfeksi HIV. Perempuan merupakan kelompok beresiko tinggi selain melakukan hubungan seksual dengan banyak pasangan, perempuan juga beresiko tertular HIV dari pasangan atau suaminya partisipan yang positif HIV. Perempuan juga beresiko menularkan HIV ke anak yang dikandungnya dari faktor MTCT (Mother to Child Transmission) (Colombini, Mutewa, Kivunaga, Stackpool, \& Mayhew , 2014)

Salah satu kendala dalam pengendalian penyakit HIV/AIDS adalah stigma dan diskriminasi terhadap penderita HIV/AIDS (ODHA) Burhan (2015). Stigma dan diskriminasi bukan hanya mempengaruhi orang yang hidup dengan HIV positif, namun juga orang-orang yang hidup disekitarnya seperti pasangan hidup, keluarga, atau bahkan perawat atau pendampingnya (Kemenkes RI, 2012).

Studi penelitian kualitatif tentang stigma dan HIV/AIDS di Papua oleh But, Morin, Numbery, Peyon \& Goo (2010) menyatakan perempuan HIV/AIDS di wilayah pegunungan Jaya Wijaya, memiliki ketakutan tentang dampak stigma. Banyak pengalaman tentang stigma dan diskriminasi dari perlakuan tidak adil, hukuman, hinaan oleh masyarakat bahkan keluarga dan orang terdekat. Dari sisi gender adanya stigma membuat mereka merasa menjadi manusia yang tidak berguna karena merasa tidak mampu memenuhi peran sosial mereka dalam keluarga, yang berkenaan dengan tanggung jawab anakanak, tanggung jawab perkawinan, pekerjaan dan kontribusi keuangan.

Hasil penelitian yang dilakukan oleh Sandolowski (2004) tentang stigma pada perempuan dengan HIV positif, menyatakan bahwa perempuan HIV positif mengalami stigmatisasi dalam hubungan dengan orang lain. Perempuan sulit sekali mengelola stigma yang dialami. Stigma berdampak negatif dalam kehidupan perempuan dengan HIV positif (Kemenkes, 2012).

Single parent adalah orang tua tunggal yang mempunyai arti ibu yang mengasuh anak-anaknya sendirian, tanpa didampingi oleh suami atau pasangan hidup (Friedman, Bowden, \& Jones, 2010). Terkadang konflik internal muncul saat perempuan single parent harus memainkan peran sebagai ibu sekaligus ayah bagi anak-anaknya.

Dalam budaya patriarki hidup dengan status single parent membawa dampak dan konotasi negatif di masyarakat terutama kaum perempuan (Imron, 2010). Permasalahan yang dihadapi perempuan single parent dengan HIV positif, merupakan permasalahan yang cukup komplek (Waluyo, et.al 2006). Mereka harus bekerja untuk menghidupi anak-anaknya dengan kondisi terinfeksi virus HIV, menghadapi efek samping dari terapi ARV, belum lagi jika kondisinya dalam keadaan sakit,dan yang paling membuat permasalahan perempuan single parent semakin komplit adalah banyak dari keluarga yang sudah tidak memperdulikan lagi kehidupan perempuan yang sudah menjadi single parent.

Banyak perempuan dengan HIV positif mengalami kekerasan yang beruntun dan menjadi komplit, seperti kekerasan secara fisik, kekerasan psikososial, kekerasan ekonomi dan lain-lain. Hal ini yang kemudian menjadi permasalahan yang berat di kehidupan perempuan HIV positif. Sampai saat ini permasalahan tersebut belum ada solusinya, dan pada akhirnya akan berdampak pada kondisi kesehatan dan penurunan kualitas hidup perempuan dengan HIV/AIDS (Haroen, Juiati \& Windani, 2008).

Provinsi Lampung, terutama di Kota Bandar Lampung merupakan kota dengan populasi penderita HIV/AIDS tertinggi di Provinsi Lampung. Bersadarkan data statistik Komisi Penanggulangan AIDS/KPA (2015) Provinsi Lampung, jumlah penderita HIV/AIDS di Lampung mencapai 1.680 orang 
pada Februari 2015. Dari jumlah tersebut, Bandar Lampung merupakan penyumbang terbesar mencapai 988 penderita. Data ststistik klinik VCT (Voluntary Counselling and Testing) Rumah Sakit Umum Daerah Abdul Muluk Provinsi Lampung membenarkan bahwa penularan HIV/AIDS melalui ibu menyumbang angka cukup besar $40 \%$. Hal tersebut dikarenakan sebagian ibu yang positif terjangkit HIV tidak mengetahui cara untuk tidak menularkan kepada anaknya serta masih banyaknya pasangan yang belum melakukan tes HIV. Stigma merupakan faktor yang menghambat akses perempuan HIV/AIDS untuk datang ke pelayanan kesehatan dan berdampak pada kualitas hidup mereka.

Beragam pendapat terkait status single parent pada sebagian besar masyarakat Indonesia masih dianggap memiliki makna yang negatif (Imron, 2010). Citra buruk selalu mengarah pada perempuan yang berlabel janda atau perempuan single parent. Kondisi perempuan HIV/AIDS dan status single parent inilah yang menarik peneliti untuk mengeksplorasi secara mendalam bagaimana stigma yang terjadi pada perempuan dengan HIV/AIDS single parent di Wilayah Kota Bandar Lampung Provinsi Lampung. Artikel ini memberikan informasi dari hasil penelitian yang bertujuan untuk memperoleh gambaran stigma pada perempuan single parent dengan HIV positif.

\section{Metode}

Penelitian ini merupakan penelitian deskriftif kualitatif dengan pendekatan konten analisis. Sampel yang diambil dengan menggunakan teknik purposive sampling. Kriteria inklusi untuk sampel penelitian adalah perempuan HIV positif yang dibuktikan melalui test elisa dari data rekam medik, berusia (15-49 th), pernah menikah dan memiliki anak, berdomisili di kota Bandar Lampung. Sedangkan, kriteria eksklusi partisipan dalam penelitian ini adalah pasien yang memiliki riwayat infeksi yang mempengaruhi fungsi kognitif, seperti meningitis atau encephalitis. Pengumpulan data mengunakan tehnik wawancara mendalam (indepth interview) dan observasi selama wawancara pada 13 partisipan.

Analisis data yang digunakan adalah analisis konten konvensional. Penelitian dilakukan dengan menerapkan etika penelitian, yaitu: (1) Respect for Human Dignity (responden berhak untuk memutuskan bergabung dalam penelitian tanpa adanya paksaan dan ancaman), (2) Respect for Privacy and Confidentially (responden memiliki privasi dan hak asasi untuk mendapatkan kerahasiaan informasi), (3) Respect for Justice Inclusiveness (berlaku adil pada semua responden), dan (4) Balancing Harm and Benefits (peneliti wajib untuk meminimalkan kerugian atau bahaya yang mungkin muncul dan memaksimalkan manfaat penelitian).

\section{Hasil}

Teridentifikasi lima tema yang memaparkan gambaran stigma pada perempuan single parent dengan HIV positif, di wilayah Kota Bandar Lampung Provinsi Lampung. Tema-tema tersebut diantaranya adalah: (1) mengalami stigma internal, (2) mengalami stigma eksternal dan diskriminasi di keluarga dan layanan kesehatan, (3) memiliki anak sebagai motivator hidup tertinggi, (4) mengalami kelelahan fisik berlebih, (5) mengalami masalah dalam memulai interaksi dengan calon pasangan hidup baru. Tema dalam penelitian ini mengambarkan stigma yang dialami perempuan single parent dengan HIV positif. Tema-tema yang telah teridentifikasi tersebut dijelaskan pada uraian di bawah ini.

\section{Mengalami stigma internal}

Mengalami stigma internal yang dimaksud dalam tema pertama ini adalah rasa takut yang dirasakan, baik itu sungguhan maupun yang diimajinasikan yang akan muncul sebagai dampak dari HIV, pada diri partisipan dan anak yang dimiliki. Tema ini terbentuk dari beberapa katagori diataranya adalah persepsi negatif yang diyakini tentang HIV, perasaan bersalah dan ketakutan karena HIV yang ditularkan ke anak. Perasaan takut ini diakibatkan karena stigma dan diskriminasi masyarakat atas 
status HIV yang dimiliki. Berikut ini merupakan beberapa kutipan yang disampaikan oleh partisipan P9:

"Sayatakut kalau orang HIV mati, takut orang enggak mau mandiin saya, takut orang jijik sama saya..." (P9).

Proses berduka yang mendalam dan rasa bersalah, juga dirasakan pada partisipan yang memiliki anak HIV positif. Hal ini diungkapkan oleh partisipan P12. Berikut salah satu kutipan yang di sampaikan oleh partisipan sebagai berikut:

"Ngerasa bersalah sama anak mbak, sekarang dia baru 9 bulan ya dia positif, sedih ngeliatnya masih kecil sudah sakit gini mbak, sedih baget, kenapa saya sudah nularin dia, padahal saya ini juga enggak tau kalau suami saya itu sakit seperti ini, taunya pas dia meninggal...” (P12).

\section{Mengalami stigma eksternal dan diskriminasi di keluarga dan layanan kesehatan}

Stigma eksternal dan diskriminasi yang dimaksud dalam tema ke dua ini adalah suatu proses yang bergerak melebihi sekedar persepsi dan sikap tetapi berbentuk tindakan tidak wajar dan perlakuan tidak adil yang dialami partisipan di keluarga dan layanan kesehatan.

Pada penelitian ini partisipan merasakan sebuah proses melebihi sekedar persepsi dan sikap tetapi berbentuk tindakan diskriminatif yang terjadi di keluarga dan layanan kesehatan. Tema ini terbentuk dari beberapa kategori yaitu perbedaan perlakuan dalam keluarga setelah membuka status HIV, kontak fisik minimal, diskriminasi di layanan kesehatan dan dilakukanya proses metode kontrasepsi permanen (tubektomi) atau sering disebut steril tanpa inform consent yang jelas. Contoh perbedaan perlakuan dalam keluarga atau diskriminasi yang terjadi di dalam keluarga meliputi pembedaan alat makan dan pakaian karena takut tertular, tidak diperkenankan masuk kamar orang HIV, tidak inggin berdekatan, persaan geli saat berjabat tangan dan mencium pipi. Berikut ini merupakan stigma eksternal yang terjadi di dalam keluarga, hal ini disampaikan oleh partisipan P1 dan P6. Berikut kutipan ungkapan yang disampaikan :

"di keluarga ketika informasi belum didapat memang semua terpiasah seperti makan minum terpisah, walaupun mereka minta maaf sebelumnya tapi tetap saja itu menyakitkan..." (P1).

"Iya kayak keluarga dari suami itu kakaknya itu gimana ngeliatnya saya datang itu dia pengen jabat tangan mau cium tangan aku kayaknya gelik gitu, Mau ngobrol dekat-dekat itu gak mau gitu..."(P6).

Tenaga kesehatan memperlakukan partisipan dan anaknya yang HIV sebagai objek tontonan di rumah sakit. Dokter menolak untuk menerima partisipan karena memiliki riwayat HIV. Hal ini sesuai dengan ungkapan yang disampaikan partisipan P6. Berikut ini merupakan kutipan ungkapan yang disampiakan oleh partisipan:

"Waktu anaku masih bayi aku kedokter umum, ku bilang kalau dia ini dulu waktu aku melahirkan aku terinfeksi HIV, dokter itu ngusir saya jadi aku tuh terasa sedih kok begini..."(P6)

Tindakan diskriminasi lain yang terjadi di layanan kesehatan adalah menempatkan partisipan dalam ruangan tersendiri, terpisah dan diisiolasi karena takut menularkan HIV ke pasien atau petugas kesehatan. Pertanyaan dan padangan miring dari petugas kesehatan juga dialami oleh partisipan. Hal ini sesuai dengan ungkapan yang disampaikan oleh partisipan P6 dan P8. Berikut ini merupakan ungkapan yang disampaikan oleh partisipan :

"Saya ditempatkan di ruangan tersendiri, perawat- perawat itu gak ada masuk ke ruangan saya..." (P8).

"Pulang dari sana malah saya nangis, iya karena perlakuannya kayak ketakutan melihat kita, trus dia gini, pas saya udah buka perban juga terus dia ngomongnya begini ini lah kalo sudah ada virus ini jadi susah kering. Padahal kondisi saya itu sangat bagus sekali, malah udah 
banyak orang yang udah lama ini juga masih apa jaitannya itu masih busuk ya bernanah, kalo saya udah kering sangat baik malah..."(P8).

Partisipan juga mengalami tindakan kontrasepsi permanen sterilisasi (tubektomi) bukan atas kehendak pribadi partisipan, hal tersebut diungkapkan oleh partisipan P6 dan P8. Berikut ini merupakan kutipan yang disampaikan oleh beberapa partisipan:

"Waktu itu saya langsung disteril iya dokter main steril aja kenapa iya dok langsung steril? dia main steril aja langsung tanda tangan ponakan ku karena suamiku meninggal, yang tanda tangan iya lagian ibu tidak akan bisa punya anak lagi katanya, anaknya sudah banyak katanya, sedih rasanya berarti saya bakal tidak punya anak lagi...."(P6).

\section{Memiliki anak sebagai motivator hidup tertinggi}

Anak sebagai motivasi hidup tertinggi yang dimaksud dalam tema ke tiga ini adalah anak merupakan penyemangat hidup bagi partisipan, dengan kondisi sebagai perempuan single parent dan terinfeksi HIV anak merupakan alasan terbesar bagi partisipan untuk tetap sehat dan bersemangat melanjutkan hidup.

Tema ini terbentuk dari beberapa kategori yaitu bersemangat hidup karena sehat dan bersemangat karena anak, anak membuat tetap bertahan, karena anak menjadi tegar dan anak merupakan motivator nomor satu. Anak merupakan motivasi terbesar yang membuat partisipan untuk mampu bertahan hidup, dengan kondisi sebagai ODHA dan kesendiriannya sebagai orang tua tunggal. Berikut ini merupakan ungkapan yang disampaikan oleh beberapa partisipan P2.

"Anak-anak yang membuat hidup saya bersemangat lagi rezeki insya Allah ada saja, yang penting saya usaha gimana caranya tetap sehat..." (P2).

\section{Mengalami kelelahan fisik berlebih}

Mengalami kelelahan fisik berlebih yang dimaksud dalam tema keempat ini adalah kelelahan dan kelemahan atau kekurangan energi, yang terjadi karena proses patologis dari penyakit HIV/AIDS dan kelelahan fisik karena bekarja ketika menjalani peran sebagai ibu dan tulang punggung keluarga.

Tema ini terbentuk dari beberapa kategori, yaitu kekhawatiran penurunan kondisi fisik terutama kelelahan karena terinfeksi HIV, dampak infeksi HIV dan ARV serta tanggung jawab sebagai orang tua tunggal, kelelahan fisik karena bekerja, dan penurunan kondisi fisik karena HIV. Berbagai kemunduran dan kelelahan fisik sering dirasakan setelah partisipan terdiagnosis HIV, keluhan utama yang dirasakan adalah adanya kelelahan dan kelemahan. Hal ini diungkapkan oleh partisipan P9. Berikut kutipan yang diungkapkan partisipan :

"Cepat lelah, cepat capek iya gak seperti dulu cuman sampai siang malam badan masih enak aja ,ini tidak ada tulangnya kayaknya lemas gitu..."(P9).

Pada penelitian ini partisipan P2 memiliki khawatiran tentang penurunan kondisi fisik yang pasti terjadi karena HIV. Berikut ungkapan yang disampaikan partisipan:

“....Ya itu tadi kalau tiba- tiba saya drop umur saya enggak panjang bagaimana anak-anak kedepannya, karena kondisi saya dengan sakit seperti ini, badan kelihatan sehat tapi bisa suatu saat drop kita enggak tahu'.....(P2).

\section{Mengalami masalah dengan hubungan lawan jenis}

Mengalami masalah dalam memulai interaksi dengan calon pasangan hidup yang baru yang dimaksud pada tema ini adalah sebagai seorang single parent tidak menutup kemungkinan mereka ingin membina hubungan dengan pasangan barunya, kondisi HIV positif memiliki stigma yang sangat mengkhawatirkan dan mengancam hubungan pribadi partisipan lawan jenisnya. 
Tema ini tersusun atas beberapa kategori diantaranya adalah merasa malu pada pasangan dengan status HIV yang dimiliki, malu memulai hubungan dengan lawan jenis, malu berinteraksi dan memilih mundur, takut menulari pasangan dan memunculkan masalah baru. ;Perasaan malu dan takut tidak diterima, ditinggalkan laki-laki karena status HIV yang dimiliki. Hal ini sesuai dengan ungkapan yang di sampaikan oleh P2.Salah satu kutipan yang disampaikan partisipan adalah sebagai berikut:

"Malu, tidak diterima karena status ini. Kalau secara pribadi saya malu untuk memulai hubungan dengan lawan jenis karena malu untuk membuka status saya mbak hanya itu. Menikah ya ingin tapi ya kembali lagi apakah pasangan saya mau menerima kondisi saya ..."(P2).

Partisipan menceritakan pengalamanya saat berusaha membina hubungan dengan pasangan barunya. Sebagai single parent, mereka tetap tidak menutup diri jika ada laki-laki yang ingin dekat dan membina hubungan ke jenjang yang lebih serius lagi. Tapi karena positif menghidap HIV, membuat mereka merasa terancam, memilih mundur dan tidak melanjutkan hubungan. Hal ini dilakukan karena takut jika membuka status HIV nya kemudian ditinggalkan atau justru membuat masalah baru dalam kehidupan mereka. Hal ini sesuai dengan ungkapan partisipan P13. Berikut ini kutipan yang disampaikan oleh partisipan:

"Malulah mbak hidup seperti ini, males rasanya mau kenal laki-laki. Ya kalau yang coba deket ada dijodohkan juga ada, cuma saya yang mundur tertur pada akhirnya. Kasihan aja takut dia tertular karena saya dia kan enggak salah apa apa mbak, nanti kalau saja jujur juga nambahin masalah orang pada tau saya seperti ini..ujung-ujungnya malah nambahin masalah bukannya saya bahagia malah runyam"...(P13)

\section{Pembahasan}

\section{Mengalami stigma internal}

Stigma internal merupakan rasa takut baik sungguhan maupun yang diimajinasikan, terhadap sikap sosial dan potensi tindak diskriminasi yang akan muncul, sebagai dampak dari atribut atas penyakit yang tidak diinginkan (misalnya HIV) atau akibat dari asosiasi pada kelompok atau perilaku tertentu Hasan, Nath, Khan, Akram, Gomes, \& Rashid (2012).

Stigma internal yang muncul dalam penelitian ini meliputi persepsi negatif yang diyakini tentang HIV, perasaan bersalah dan kecamasan karena menularkan HIV ke anak. Sebagai seorang single mother dengan HIV positif stigma internal bukan hanya muncul pada diri partisipan sebagai ODHA, tetapi juga anak yang dimiliki. Hal ini sejalan dengan penelitian yang dilakukan Hunter(2004), yang menyatakan bahwa ;persepsi stigma oleh ibu dengan HIV positif muncul karena asumsi masyarakat tentang kemampuan perempuan untuk melahirkan dan membesarkan anak.

Pada penelitian ini sebagain besar suami partisipan baru membuka status mereka sebagai ODHA, ketika mereka sudah jatuh sakit dan memasuki tahapan proses daying karna penyakit AIDS. Partisipan tidak melakukan pencegahan apapun, agar HIV tidak menular ke anak, mulai dari proses kehamilan, melahirkan, sampai dengan praktek pemberian air susu ibu (ASI). Hal ini terjadi pada partisipan karena mereka tidak tahu dirinya juga telah positif terinfeksi HIV.

Perempuan memiliki sensitivitas yang tinggi terhadap penularan HIV/AIDS, mengingat peran perempuan sebagai istri dan ibu bagi anak mereka yang akan melanjutkan garis keturunan (Noor, 2015). Perempuan tidak berdaya untuk melindungi diri mereka sendiri dari paksaan permintaan suami untuk dilayani, termasuk juga pemikiran masyarakat kita yang terbudaya bahwa istri memiliki kewajiban untuk patuh pada instruksi suami. Keterbatasan pengetahuan dan budaya patriarki inilah menjadi faktor utama yang menyebabkan faktor menularnya HIV dan terabaikannya hak-hak kesehatan reproduksi wanita (Noor, 2015). Satu hal yang menjadi kontroversi bahwa sesuai teori virus HIV menular melalui pergaulan bebas dan norkoba, namun yang terjadi sebaliknya partisi;pan justru tertular dari suaminya. 
Perempuan dalam penelitian ini mendapatkan stigma negatif di masyarakat atas penyakit yang di deritanya. Partisipan harus menjalani beban stigma negatif ganda, yakni sebagai penderita HIV dan dikucilkan dari kehidupan masyarakat. Stigma internal lain yang muncul dalam penelitian ini diantaranya meliputi rasa takut apakah si anak akan mampu tetap sehat bertahan hidup dengan kondisi terinfeksi HIV, apakah lingkungan disekitarnya seperti teman-teman, guru disekolahnya bisa menerima keberadaannya sebagai penderita HIV, apakah si anak mampu menerima bahwa dirinya terinfeksi HIV karna tertular oleh ibunya.

\section{Mengalami stigma eksternal dan diskriminasi di keluarga dan layanan kesehatan}

Stigma eksternal dideskripsikan sebagai proses yang bergerak melebihi sekedar persepsi dan sikap sehingga bentuk tindakan (Kemenkes RI, 2012). Stigma eksternal secara konsisten mengikuti pola tiga langkah yaitu: (1) mengidentifikasi yang terinfeksi HIV, (2) membuat jarak dengan orang-orang tersebut, dan (3) membatasi atau tidak mengikutsertakan orang-orang tersebut (Morrison, 2006). Stigma eksternal sering diwujudkan dengan adanya pengemukaan atau pelanggaran hak kerahasiaan terhadap tes HIV atau sering disebut sebagai enacted stigma begitu juga dengan tindak labeling, penghindaran, isolasi dan segregasi pada ODHA (Visser, Makin, Miller, Forehand, Sikkema, \& Forsyth, 2009). Pada penelitian stigma eksternal dan diskriminasi sangat dirasakan sekali oleh partisipan, terutama di layanan kesehatan dan lingkungan keluarga.

\section{Stigma eksternal dan diskriminasi di keluarga}

Bentuk stigma dan diskriminasi yang dialami partisipan keluarga dalam penelitian ini diantaranya seperti menempatkan partisipan dan anaknya di rungan tersendiri, memisahkan alat makan dan pakaiannya dengan anggota keluarga yang lain, pertanyaan halus yang kadang menyakitkan, serta sikap kehati-hatian yang berlebihan dari anggota keluarga.

Penelitian yang dilakukan oleh Waluyo, Sukamarini, dan Rosakawati (2006) menyatakan, stigma merupakan masalah yang terjadi di mana-mana, dan tidak hanya terjadi pada negara dengan latar belakang budaya, sosial dan agama tertentu. Kedua, diketahui ada indikasi yang menunjukkan bahwa pengetahuan dan pemahaman tentang HIV/AIDS masyarakat rendah. Kedua hal ini saling berkaitan karena rendahnya pengetahuan masyarakat tentang HIV/AIDS akan memicu munculnya stigma.

Di keluarga dan komunitas partisipan sangat menjaga sekali statusnya sebagai perempuan positif. Ada beberapa hal yang terjadi dalam penelitian ini, partisipan yang tertutup sama sekali termasuk kepada ibu kandungnya sendiri dan keluarga terdekatnya. Hal ini sesuai dengan penelitian yang dilakukan oleh Swendeman, Rotheram-Borus, Comulada, Weiss, \& Ramos (2006) yang menyatakan bahwa perempuan dengan HIV/AIDS sangat menjaga status HIV mereka dari keluarga, pasangan dan masyarakat, karena takut akan reaksi dari masyarakat, juga untuk melindungi anak-anak mereka dari stigma dan diskriminasi di lingkungannya.

\section{Stigma eksternal dan diskriminasi di layanan kesehatan}

Eksternal stigma dan diskriminasi yang terjadi di layanan kesehatan pada penelitian ini meliputi, pengalaman yang sangat tidak menyenangkan, diusir dari pelayanan kesehatan, menjadi bahan tontonan oleh petugas kesehatan. Kehilangan hak untuk menentukan masa depan reproduksi mereka karena disteril atau dilakukan prosedur tubektomi tanpa inform consent yang jelas oleh petugas kesehatan setelah persalinan.

Penyebab tingginya stigma pada layanan kesehatan disebabkan oleh beberapa faktor diantaranya adalah pengetahuan tentang HIV/AIDS yang masih rendah (Waluyo, 2015). Pengetahuan dan pemahaman tentang HIV sangat mempengaruhi bagaimana individu tersebut akan bersikap terhadap penderita HIV/AIDS (Paryati, 2012). 
Penelitian yang dilakukan Mahendra et al. (2006) yang menyatakan bahwa jenis tenaga kesehatan sesuai dengan latar belakang pendidikannya mempengaruhi skor stigma dan diskriminasi terhadap ODHA. Studipenelitian yang dilakukan oleh Waluyo, Culbert, Levy dan Norr, (2015) menyatakan bahwa stigma di layanan kesehatan masih cukup tinggi di Indonesia. Menurut Waluyo et al. (2015), tingginya stigma pada layanan kesehatan disebabkan oleh pengetahuan tentang HIV/AIDS yang masih rendah.

\section{Memiliki anak sebagai motivator hidup tertinggi}

Motivator merupakan seseorang atau penyemangat yang menyebabkan timbulnya motivasi pada orang lain untuk melaksanakan sesuatu atau mencapai tujuannya. Keluarga yang dimiliki adalah kesatuan antara ibu dan anak. Hilangnya sosok suami, atau figure seorang ayah dalam keluarga single parent, menempatkan anak berada pada posisi tertinggi sebagai harapan dan motivator dalam kehidupan partisipan. Anak memberikan dorongan untuk lebih bersemangat bekerja karena sudah memiliki tanggungan hidup (Zulfitri, 2013).

Perbedaan nilai anak pada perempuan single parent dengan HIV positif dalam penelitian ini, adalah anak merupakan seseorang yang mampu membuat partisipan tetap bertahan hidup, berupaya untuk tetap sehat, dan memiliki semangat hidup dalam kondisi sakit, karna infeksi virus HIV dan menghadapi stigma dengan status yang dimilikinya.

Banyak orang beranggapan bahwa tugas sebagai orang tua tunggal jauh lebih sulit dibandingkan dengan dua orang tua yang bersama-sama membesarkan dan mendidik anak partisipan. Ada beberapa faktor yang menyebabkan hal ini terjadi diantaranya adalah masalah ekonomi dan sumber daya psikologis dalam mendidik dan membesarkan anak (Usakli, 2013).

Pada penelitian ini nilai anak bagi perempuan single parent dengan HIV positif adalah lebih kepada nilai psikologis. Anak memberikan kebahagian bagi partisipan. Anak merupakan sebuah alasan dan tujuan untuk tetap bertahan hidup. Keluarga besar partisipan sangat membantu tugas partisipan dalam menjalankan peranya sebagai orang tua tunggal. Dukungan dan bantuan yang diberikan keluarga besar partispan membuat hidup mereka jauh lebih baik.

\section{Mengalami kelelahan fisik berlebih}

Fatigue atau kelelahan didefinisikan sebagai perasaan subjektif terhadap kelelahan dan kelemahan atau kekurangan energi (Rabdruch, 2008). Penyebab fatigue sampai sekarang masih menjadi perdebatan. Hasil penelitian yang dilakukan (Dillinger, 2007; Rabdurch, 2008) menyatakan bahwa fatigue pada infeksi HIV disebabkan karena infeksi sekunder atau infeksi oportunistik, anemia, asupan gizi yang kurang gangguan hormon, dehidrasi dan masalah psikologis yang menjadi penyebab penting dari kelelahan atau fatigue.

James (2015)juga menyatakan bahwa depresi dan kelainan hormon merupakan dua penyebab kelelahan yang dialami penderita HIV. Pada penelitian ini partisipan mengalami ini kelelahan yang berlebih melibatkan fisik (physical/ muscular fatigue) dan kelelahan psikologi (ps;ychological fatigue). Menurut partisipan kelelahan fisik atau (physical/ muscular fatigue) ini diakibatkan oleh double pekerjanan dalam menjalankan perannya sebagai ibu dan tulang pungung keluarga.

Pada penelitian ini, tidak dilakukan secara mendalam hubungan HIV dengan kelelahan, tetapi menurut James (2015) keterbatasan energi merupaka salah satu faktor pemicu timbulanya kelelahan. James (2015) menyatakan bahwa penggunaan energi untuk mengerjakan pekerjaan atau kegiatan sehari-hari pada orang yang terinfeksi virus HIV jauh lebih besar dibandingkan orang biasa pada umumnya. Pada orang yang terinfeksi virus HIV kebutuhan akan oksigen di sel-sel otot untuk melakukan metabolisme untuk mensintesa energi jauh lebih tinggi dibandingkan orang yang sehat (Black \& Hawks, 2014). 
Dalam penelitian ini partisipan juga mengalami kelelahan psikologi (psychological fatigue). Menurut Dillinger (2007) masalah psikologis yang dihadapi pasien HIV, berperan menyebabkan kelelahan atau fatigue.

Partisipan penelitian ini mengalami berbagai perubahan psikologi yang terjadi pasca terdiagnosis HIV. Perasaan ketakutan, sedih dan bersalah karena telah terdiangnosis HIV dan menularkan ke anaknya, kecemasan dan kehawatiran untuk tidak diterima di lingkunganya karena kondisi HIV yang sekarang diderita. Partisipan juga merasa terancam dan takut membayangkan stigma yang akan dialami diri dan anaknya sebagai penderita HIV. Hal inilah yang memicu timbulya tekanla psikologis dan depresi pada diri partisipan. Hal ini sejalan dengan penelitian yang dilakukan oleh Rayasari (2015) yang menyatakan bahwa stigma dan diskriminasi juga merupakan salah satu pen;yebab yang memperberat reaksi dan masalah psikologis yang dialami penderita HIV.

Fatigue dan depresi berkaiatan erat pada penderita HIV (Kusuma, Nurachmah, \& Gayatri, 2010). Permasalahan atau hambatan yang muncul pada pada partisipan diantaranya adalah masalah kelelahan fisik yang berlebih karna tekanan psikologis yang dialami. Secara biokimia depresi mengakibatkan tingkat serotonin, norepinefrin, atau dua-duanya jauh dibawah normal dan ini bisa mengakibatkan gejala kelelahan fisik dan mental (James, 2015). Sistem imun melindungi tubuh dengan cara mengendalikan bakteri atau virus kedalam tubuh dan bereaksi terhadapnya. Ketika sistem imun tubuh melemah, dan diperberat dengan adanya stesor psikologis maka tubuh akan lebih mudah terinfeksi, termasuk infeksi yang disebabkan oleh virus HIV, tubuh akan mudah terkena infeksi oportunistik (Hofman, Rockstroht, Kamps, 2006). Akibat dari infeksi yang berkepanjangan dan gangguan pada hampir semua sistem tubuh maka akan berdampak pada masalah fisik dan psikologis. Salah satu gejala umum yang dilaporkan oleh seseorang yang terinfeksi HIV dampak dari masalah fisik dan psikologis tersebut adalah kelelahan atau fatigue (Jenkie et al, 2006).

\section{Mengalami Masalah dalam Memulai Interaksi dengan Calon Pasangan Hidup yang Baru}

Partisipan penelitian ini mengalami masalah memulai interaksi dengan calon pasangan hidup yang baru. Permasalah itu berupa perasaan takut menulari pasanganya, takut untuk berumah tangga. Partisipan tidak membuka statusnya sebagai perempuan HIV karena takut ditinggalkan pasangannya serta adanya kecenderungan partisipan untuk memilih ODHA sebagai pasangan hidupnya. Hal ini terjadi karena sebagaian besar partisipan, tidak ingin menambah masalah baru dalam kehidupan rumah tangganya kelak termasuk bagi anak-anaknya, partisipan juga tidak ingin terbebani secara moril jika suatu saat nanti pasangannya tertular.

Status single parent yang sekarang dialami oleh sebagian besar partisipan terjadi oleh karena pasangan mereka meninggal dunia karena AIDS, bukan karena adanya perceraian ataupun konflik dalam rumah tangga. Menyandang status sebagai perempuan single parent atau janda dalam budaya partriarki dianggap masyarakat sebagai sesuatu hal yang menyimpang dari norma masyarakat, selayaknya suami didampingi oleh istri dan itu, merupakan suatu hal yang menjadi keharusan (Ghani, 2013). Penyebab single parent sangat menpengaruhi konsep diri mereka dalam berhubungan dengan orang lain, anggap masyarakat dengan status single parent dikarenakan pasangan meninggal membuat mereka lebih mampu menjalani permasalahan hidup dan mitos yang berkembang di masyarakat kerap dihadapi pada keluarga single parent. Menurut Wahyuni (2010) alasan seseorang menjadi orang tua tunggal sangat mempengaruhi mitos-mitos yang berkembang di masyarakat.

Partisipan penelitian ini mempunyai perasaan malu dan takut jika harus membuka status mereka sebagai seorang HIV pada pasangan lawan jenisnya.Hal ini terjadi dikarenakan perasaan takut mengewakan dan ditinggalkan. Stigma yang dialami sebagai seorang single parent dan HIV positif sangat mempengaruhi interaksi sosial mereka di masyarakat. Hasil penelitian yang dilakukan oleh Sandolowski (2004) tentang stigma pada perempuan dengan HIV positif menyatakan perempuan HIV 
positif mengalami stigmatisasi dalam hubungan dengan orang lain. Partisipan menyatakan lebih nyaman membina hubungan dengan sesama ODHA. Hidup bersama sesama ODHA membuat mereka tidak mengalami tekanan secara psikologis karena beresiko menulari pasangannya yang sehat. Menurut Mardiati dan Handayani (2011), dukungan sebaya mampu meningkatkan konsep diri yang positif. Hal ini sesuai dengan penelitian yang dilakukan oleh Diatmi \& Fridari (2014) menyatakan bahwa di Indonesia dukungan keluarga dan masyarakat yang diterima ODHA mampu meredakan kecemasan atau kondisi stress yang muncul terkait dengan kondisi sakit yang dialaminya. Dengan dukungan sosial yang didapatkan ODHA, mampu menurunkan stigma yang dialami dan mampu meraih kualitas hidup yang lebih baik.

\section{Simpulan}

Perempuan single parent mengalami stigma ganda, yaitu stigma internal dan eksternal. Partisipan perempuan single parent dengan HIV positif pentingnya mencari dukungan dari orang terdekat yang dipercaya, seperti keluarga atau tenaga kesehatan, karena ia membutuhkan dukungan yang lebih, dibandingkan perempuan HIV yang lain, oleh karena double stigma yang dirasakan oleh partisipan. Keluarga merupakan support sistem terbesar bagi perempuan single parent, dukungan dan bantuan keluarga dalam segala hal dirasakan sekali manfaatnya bagi partisipan. Stigma dan diskriminasi terhadap perempuan HIV muncul disebabkan tidak tahu tentang mekanisme penularan HIV, perkiraan risiko tertular yang berlebihan melalui kontak biasa dan sikap negatif terhadap kelompok sosial yang tidak proporsional yang dipengaruhi oleh epidemi HIV/AIDS dan salah satu penyebab terjadinya stigma adalah misinformasi mengenai bagaimana HIV ditransmisikan.

Perlunya pembekalan pengetahuan tenaga kesehatan mengenai stigma dan diskriminasi dan kemampuan pencegahan HIV/AIDS di masyarakat, disamping pelayanan yang paripurna diharapkan bisa menghapus stigma dan diskriminasi. Program dan keterampilan praktis untuk mengatasi stigma dan diskriminasi, terutama dikalangan tenaga kesehatan dan masyarakat perlu dilanjutkan dan ditingkatkan. Perlunya dukungan sosial yang lebih dibandingkan perempuan HIV lainnya, karena double stigma yang dialami, sebagai perempuan HIV positif dan perempuan single parent.

\section{Referensi}

Arga, R. (2015). Komisi Penanggulangan AIDS.

Black, J.M. \& Hawks, J.H. (2014). Keperawatan medikal bedah menajemen klinis untuk hasil yang diharapkan. (A.Susula, F.Ganiarji, P.P Lestari \& A.R.W. Sari, Eds.) (8 th ed.). Singapore: Elsevier Ltd.

Burhan, R. (2015). Pemanfaatan pelayanan kesehatan oleh perempuan terinfeksi HIV /AIDS. Health Service Utilization in Women Living with HIV / AIDS, (03), 33-38.

Butt, L., Morin, J., Numbery, G., Peyon, I. \& Goo, A. (2010). Stigma and HIV/ADIS Papua. Research Collaboration: Pusat Studi Kependudukan -UNICEF, Abepura, Papua And Uneversity Victoria, Canada.

Colombini, M., Mutemwa, R., Kivunaga, J., Stackpool Moore, L., \& Mayhew, S. H. (2014). Experiences of stigma among women living with HIV attending sexual and reproductive health services in Kenya: a qualitative study. BMC Health Services Research, 14(1), 412. doi:10.1186/1472-6963-14-412

Diatmi, K., Fridari, D. (2014). Hubungan antara dukungan sosial dengan kualitas hidup pada orang dengan HIV. Jurnal Psikologi Udayana. Vol. 1, No. 2, 353-36.

Dillinger, M. (2007). Nursing care of patients with HIV disease and AIDS, dalam Linda S. Williams \& Pa.ala, D Undetstanding medical-surgical nursing 3"t edition ;hal 321 -341, Davis Company.

Mariyn, M.F., Vicky, R.B., Eline, G., Jones, F. \& Marilyn, M. (2010). Buku ajar keperawatan keluarga: riset,teori \& praktik. Ed 5. Jakarta: ECG.

Ghani, A. \& Aziz, A. (2013). Profile of single mother in southern malaysia and issues afflicting their lives. Brithis Journal Of Art and Sosial Sciences. 
Haroen, H., Juniarti, N., \& Windari, C. (2008). Kualitas hidup wanita penderita AIDS dan wanita pasangan penderita AIDS di Kabupaten Bandung Barat. Jurnal Ilmiah Keperawatan. 10(18). 1-16.

Hasan, T., Nath, S. R., Khan, N. S., Akram, O., Gomes, T. M., \& Rashid, S. F. (2012). Internalized HIV / AIDSrelated Stigma in a Sample of HIV-positive people in Bangladesh, 30(1), 22-30.

Hofman. L.W., Manis J, D., (1979). The value of children in the united states; a new approach to the study of fertility. Journal of Marriage And The Family. From: http;/www.jstor. org

Hunter, S. T. (2004) “Iran’s Pragmatic Regional Policy”; Journal of InternationalAffairs, 56(2), (springler).

Imron, A.A.,(2010). Pencitraan Perempuan Pasca Percaeraian Dalam Prespektif Gender Jurnal Universitas Islam Malang. UIN Press Malang

James. J. (2015). Kelelahan dan HIV. http://spiritia.or.id/ .Diunduh 1 Februari 2015

Jenkie P. et al. (2006). The experience of fatigue foradults living with HIV Journal of Clinical Nursing 15, 11231131.

Kemenkes RI.(2012) . Penghapusan Stigma dan Diskriminasi Bagi pengelola program,petugas layanan keehatan dan kader, Kementrian kesehata RIDirektoral jedral pengendalian dan penyehatan lingkungan pengendalian penyakit menular langsung. Jakarta.Kemenkes RI.

Kusuma, H., Nurachmah, E., \& Gayatri, D. (2010). Hubungan antara depresi dan dukungan keluarga dengan kualitas hidup pasien HIVI AIDS yang mengalami perawatan di RSUP, Cipto Mangunkusumo Jakarta. Tesis Program S2 Fakultas Ilmu Keperawatan Universitas Indonesia, tidak dipublikasikan.

Mardhiati, R., Handayani, S. (2011). Peran Dukungan Sebaya Terhadap Peningkatan Mutu Hidup ODHA Di Indonesia Tahun 2011. Yayasan Spiritia dan Lembaga Penelitian Pengembangan Universitas Muhammadiyah Prof. DR. Hamka.

Mahendra, V. S., L. Gilborn, B. George, L. Samson, R. Mudoi, S. Jadav, I. Gupta, S. Bharat and C. Daly (2006). Reducing AIDS-related stigma and discrimination in Indian hospitals. Horizons Final Report. New Delhi, Population Council.

Morrison, K. (2006) . "Breaking the Cycle: Stigma, Discrimination, Internal Stigma, and HIV.” Washington DC: Futures Group, POLICY Project.

Noor, H. (2015). AIDS dan Masa Depan Perempuan . http://spiritia.or.id/. Diunduh 8 Januari 2015

Paryati, T., Raksanagara, A. S., \& Afriandi, I. (2012). Faktor-faktor yang Mempengaruhi Stigma dan Diskriminasi kepada ODHA (Orang dengan HIV / AIDS) oleh petugas kesehatan : kajian literatur Factors Influencing Stigmatization and Discrimination of PLHA (People living with HIV / AIDS) among health workers: literature review, (38), 1-11.

Radbruch, L. et al. (2008). Fatigue in palliative care patierts an EAPC approach. Palliatt.,e Medicine,22. hal 1332

Rayasari, F.( 2014). Depresi, Self Care Practice dan Tingkat Fatigue Pada Pasien HIV POSITIF. Jurnal Keperawatan Vol.1.1.hal1-68 edisi mai 2014. ISSN 2355-9624

Sandelowski, M.,Lambe, C \& Barroso, J.(2004) Stigma in HIV-Positif Women methaasynthesis. Stigma and HIVPositif Women. Journal of Nursing Scholarship. Doi: 10.1111/j.1547-5069.2004.04024.x.

Swendeman, D., Rotheram-Borus, M. J., Comulada, S., Weiss, R., \& Ramos, M. E. (2006). Predictors of HIVrelated stigma among young people living with HIV. Health Psychology : Official Journal of the Division of Health Psychology, American Psychological Association, 25(4), 501-9. doi:10.1037/02786133.25.4.501.

UNSAIDS. (2012) The internalization Stigma RelatedtoHIV.http://www.unaids.org/dokuments(2012). Diperoleh Februari 2015.

UNAIDS. (2014). UNAIDS report on theglobal AIDS epidemi'. Children, HIV and AIDS. Available from URL http://www.avert.org/children.htm.

Usakli, H. (2013). Comparison of Single and Two Parent Childrend in Terms of Behaviour and Tendencies. International Journal of Humanities and Social Science. Vol 3 No 8 (Special Issue ). http;// www.ijhsneet.com. 
Visser, M.J., Jennifer, D.M., Vandormael, A., Sikkema, J.K.., \&Brian, W.C. (2009). HIV POSITIF stigma in a South African community.AIDS care, 21(2), 197-206. doi:10.1080/09540120801932157.

Wayuni, SD. (2010). Konflik Dalam Keluarga Single Parent. Skripsi. : Fakultas Ilmu Sosial Dan Ilmu Politik Universitas Indonesia .

Waluyo, A., Sukamrini, L., Roskawati. (2006). Persepsi Pasien HIV/AIDS dan Keluarganya tentang HIV/AIDS dan Stigma Masyarakat Terhadapnya. Jurnal Keperawatan Indonesia, Volume 10, No.1.

Waluyo, A., Culbert, G.J., Levy, J., \& Norr, K.F. (2015). Understanding HIV-related stigma among indonesian nurses. Journal of The Association of Nurses in Aids Care, 26(1), 69-80 .doi 10.1016/j.jana.2014.03.001.

Zulfitri, N, M. (2013). Studi Deskriptif: Nilai Anak Bagi Orang Tua yang Memiliki Anak Tunggal. Jurnal Ilmiah Mahasiswa Universitas Surabaya. Vol 2 No.2. 